\title{
ANALYSIS OF THE RELATIONSHIP BETWEEN THE QUALITY OF PRESENCE OF DESTINATION THROUGH ONLINE TRAVEL CONTEXTS, ATTITUDE, AND INTENTION; CASE OF IRAN
}

\author{
iD Zahed Ghaderi ${ }^{1}$ \\ Dasoul Shahabi ${ }^{2+}$ \\ Amir Hossein \\ Qezelbash $^{3}$
}

\author{
${ }^{\prime}$ Kharazmi University, Department of Business and Tourism, Tehran, Iran. \\ Email:zahedghaderi@yahoo.com Tel: +989125134887 \\ ${ }^{2}$ University of Tehran, Department of Management and Marketing, Tehran, \\ Iran. \\ Email:Rasoulshahabi@alumni.ut.ac.ir Tel: +989378592855 \\ ${ }^{s}$ University of Florence, Department of Economics and Management, Via \\ delle Pandette, Italy. \\ Email:amir.qezelbash@stud.unifi.it Tel:+989109245019
}

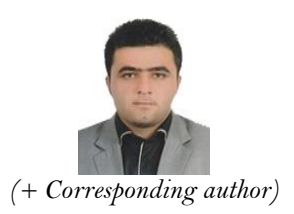

ABSTRACT

\section{Article History}

Received: 11 August 2020 Revised: 15 September 2020 Accepted: 29 September 2020 Published: 9 October 2020

\section{Keywords}

Tourist's attitude Quality of website Destination online contexts (DOCs) TPB EWOM.

\begin{abstract}
Advancing in the Internet and digital breakthroughs in communication tools bring various transformations in tourism industry requiring invasive studies about travel destinations online presence, and tourists' online behavior. It is important to investigate and analyze the role of online environment, in general, and tourism online contexts, in particular on the formation of tourist's desires and attitude toward the destination in order to manage and provide an appropriate image of the destination. The current study examined how online travel materials affect tourist attitudes and decisionmaking in visiting a destination. A quantitative research method, using a sample of 456 respondents of international tourists visiting Iran in 2016 was applied. Applying partial least square method, the results showed that the quality of websites, satisfaction, trust, and perceived usefulness have a positive impact on the tourists' attitude and destination selection. Furthermore, perceived usefulness of the destination online contexts (DOCs) positively affects the user's satisfaction and it also positively affects the continuous intention to use DOCs. Unlike previous researches we also found a positive relationship between design quality and DOCs confirmation. In addition, theoretical and practical implications of the findings were discussed.
\end{abstract}

Contribution/Originality: This study contributes to the existing literature by comparing the effects of DOCs on the attitude and intention of two types of tourists (we call them; multi- platform users, and single platform users) which lead in more diagnostic, precise, and realistic results. Moreover, understanding the whole effects of DOCs on tourists travel behavior will help destination managers and practitioners to revise their marketing and promotional strategies to fulfill tourists' needs.

\section{INTRODUCTION}

The significant role of Internet and Information Technology (IT) in promoting and advancing tourist destinations is not deniable, and researchers specifically highlighted how information technology has assisted Destination Management Organizations (DMOs) to promote their products and services through online platforms (Buhalis \& Law, 2008; Kim, Chung, \& Lee, 2011; Xiang, Magnini, \& Fesenmaier, 2015). IT has intensely transformed the travel and tourism to the new era, and internet provides plentiful amount of information for various users (Sparrow, Liu, \& Wegner, 2011). Searching tools such as search engines have become dominant tools that influence how, when and where travelers should decide to go (Xiang, Wöber, \& Fesenmaier, 2008), placing 
destinations in a severe competitive edge. Arguably, factors such as diffusion of information, growth of fast Internet services, and maturation of the Internet-related technologies, have accelerated and impacted tourists' planning and decision-making for choosing the desired destination (Beldona, 2005). Sufficient and appropriate internet contents, as well as fast appearance in internet search engines are influential factors in destination selection (Ghaderi, Hatamifar, \& Henderson, 2018). While many studies investigated the role of technology in travel behavior (Davis, 1989; Davis, Bagozzi, \& Warshaw, 1989; Taylor \& Todd, 1995; Venkatesh \& Davis, 2000) tourist attitudes towards destinations in post and pre-visits (Baloglu, Henthorne, \& Sahin, 2014; Choi, Law, \& Heo, 2016; Riscinto-Kozub \& Childs, 2012), investigating the impacts of one specific website on the perception of travelers (Lee, Chung, \& Nam, 2019).

Additionally; Chung, Lee, Lee, and Koo (2015) stated that portal managers at tourist destinations can persuade tourists to visit a destination by producing useful and user-oriented contexts. Therefore, it is important to understand how online environment can affect tourists' perception and their decision to choose a particular destination. Previous studies introduced several important factors which have positively affected users such as website quality, e-trust, e-satisfaction, usefulness, security, source of information, reviews, e-WOM, etc. (AlcántaraPilar, Blanco-Encomienda, Armenski, \& Del Barrio-García, 2018; Ayeh, Au, \& Law, 2013a; Bhattacherjee \& Premkumar, 2004; DeLone \& McLean, 1992; Gang \& Taeho, 2018). However, there is an obvious gap in these studies, because as mentioned by Alcántara-Pilar et al. (2018) It seems that investigating the power of destination online contexts received limited attention and researchers called for further investigations based on the real destination websites, because many researchers have designed website of a fictitious destination which may affect respondents' attention and final results (Alcántara-Pilar et al., 2018). This gap comes to be more noticable when we know that a lot of travellers are multi-platform users rather than being single platform users. Thanks to the adavances of the Internet, users have diverse virtual platforms to find information, services, and necessary recommendations. Therefore, a compherensive study by diving users based numbers of online platforms they are using before visiting a destination, and comparing the results would be more helpful to realize which components and elements of DOCs can affect users, as long as multi- users are being disposed to many various platforms. For example, while googling "Iran", many online contexts appear to give information about it. Some of them give positive, but some others discourage travelers travelling to Iran, and general websites presents a huge amount of the divergent recommendations, complains and issues. Supposing that travelers browse a lot of DOCs to find information and make their plan, this study by adopting Delone and Mclean's model with ECM (ExpectationConfirmation Model), TPB (theory of planned behavior), examines how DOCs can shape tourists' attitude. We have four reasons to employ these theories. In this study, we tried to explore the whole effects of online destination platforms, their overall qualities, usefulness, and trust on tourist's attitude and intention to visit a destination, and compare these effects of DOCs with effects of a single platform (TripAdvisor). Therefore, the main contribution of this study could be that by comparing the effects of DOCs on the attitude and intention of two types of tourists (we call them; multi- platform users, and single platform users) results would be more diagnostic, precise, and realistic.

Understanding the whole effects of DOCs on tourists travel behavior will help DMOs to revise their marketing and promotional strategies to fulfill tourists' needs. Indeed, the term destination online contexts (DOCs) in this study, refers to all websites, pages, blogs, and other online sources which provide information about a specific destination, even if they are external sources outside of the country such as; lonely planet, Trip advisor, Facebook or even Embassies' websites.

\section{LITRATURE REVIEW}

\subsection{Websites Qualities}

As the Internet is widely used around the world, it is crucial for DMOs to present an excellent performance of themselves in the growing online environment. According to DeLone and McLean (1992), an information system 
(IS) is a structure that information is its main output. They considered three quality dimensions for a successful system. According to the Delone and Mclean (2014) updated IS success model "system quality", "information quality" and "service quality" are independent variables that influence the "usage process" and "user satisfaction". The system quality measures both the desired characteristics of the web content and the quality of online information. Personalization, inclusiveness, relevancy, easy to understand and secure e-transactions are the important factors for having a well-qualified system. System quality measures the desired characteristics of the ecommerce system such as usability, availability, reliability, adaptability and also response time (Delone \& Mclean, 2014). The service quality measures all supported services which providers have promised to their customers (Ayeh et al., 2013a; Bronner \& Hoog, 2016; Chung et al., 2015; Lee et al., 2019).

The importance of service quality is most likely greater than the other above-mentioned factors, because at this stage, potential users have become real customers (Delone \& Mclean, 2014). According to Jung (2009) three quality dimensions (service, information, and system quality) positively influence the usage and satisfaction. These qualities are adopted in a number of studies which have evaluated various types of information systems (Chung et al., 2015; Ho, Kuo, \& Lin, 2012; Reza, Samiei, Dini, \& Yaghoubi, 2012). Some researchers have also used the design quality instead of the service quality. For example, Lee and Chung (2009) evaluated the quality of mobile banking and measured the design quality instead of service quality, they also found out that the interface design quality affects satisfaction and trust as a moderating variable. In a similar way, Chung et al. (2015) pointed out that the bad website design might cause unnecessary hassles or negative effects on the utilization environment. Therefore, in this study, three quality dimensions (information, service, design quality) are applied in order to proceed a further investigation of DOCs.

\subsection{Expectation-Confirmation Model (ECM)}

ECM is widely used to explore the user's behavior in an IS Post-adoption environment (Lai, Chen, \& Chang, 2016). The ECM focuses on the customer's continuous use of the internet after its acceptance; so, it provides a solid explanation, and a long-term scale projection with consumer's behavior (Bhattacherjee, 2001). Confirmation is the extent to which users confirm the performance of the information system (Lai et al., 2016). The more the websites are well qualified, the more they meet user's expectation. Therefore, it is expected that the three websites qualities (information, service, and design) positively associate with the website's confirmation (Chung et al., 2015; Lee \& Chung, 2009). On this account, the following hypotheses can be made:

H1: Information quality of the DOCs positively affects tourist's confirmation.

H2: Service quality of the DOCs positively affects tourist's confirmation.

H3: Design quality of the DOCs positively affects tourist's confirmation.

\subsection{Confirmation, Perceived Usefulness, and Satisfaction}

In the ECM, confirmation is a stronger predictor that has positive impacts on both perceived usefulness and satisfaction (Ambalov, 2018; Lai et al., 2016). In this model, Perceived usefulness is the extent to which a person expects that using an information system contributes to their performance (Lai et al., 2016). Satisfaction determines overall user's opinion about the IS, which shows an emotion-based response to the target of IS (Lam, Shankar, Erramilli, \& Murthy, 2004). Empirical evidences on the IS continuance usage show that user's satisfaction is the most important factor of the IS continuance intention (Thong, Hong, \& Tam, 2006). When users recognize that the performance of a new technology fulfil their expectations, the usefulness of the so called technology is perceived. Anol Bhattacherjee and Barfar (2011) stated that in the age of the Internet which provides a wide range of applications for user (such as video games, virtual reality software, social networks, etc.) description of perceived usefulness contains all the benefits users expect to achieve by using a special online platform. Confirmation, 
particularly in customer behavior, is positively related to the satisfaction with the IS, whenever customers realize the expected benefits of the IS use (Bhattacherjee, 2001). Therefore:

H4: Tourists' confirmation of the DOCs positively affects perceived usefulness.

H5: Tourists' confirmation of the DOCs positively affects satisfaction.

\subsection{Perceived Usefulness, Satisfaction, and Continuous Usage Intention}

In the ECM, users' expectations are prolonged in the perceived usefulness. It implies that users have some expectations before using an IS, and perceived usefulness depends on the extent of rewarding these expectations after using IS. Accordingly, perceived usefulness is a concrete determinant in deciding to further use the IS in the future (Bhattacherjee \& Lin, 2014). Therefore, perceived usefulness is a perception that users expect to achieve, when they are using an IS (Davis, 1989). Based on the travelers' requirements, when they search for information, we can define the usefulness as the amount of DOCs required for tourists to take into account in trip planning and decision-making process. The perceived usefulness plays a great role in triggering user's intention to continue using a special IS (Ambalov, 2018; Davis, 1989; Karahanna, Straub, \& Chervany, 1999; Lai et al., 2016). It is especially consistent with the usage continuous intention (Agarwal \& Karahanna, 2000; Bhattacherjee \& Premkumar, 2004) the satisfaction (Alcántara-Pilar et al., 2018; Bhattacherjee, 2001; Limayem \& Cheung, 2008) and attitude (Bhattacherjee \& Hikmet, 2008). Hence:

H6: Perceived usefulness of DOCs positively affects user's satisfaction.

H7: Perceived usefulness positively affects the continuous intention to use DOCs in searching for information about Iran.

H8: Satisfaction positively affects the continuous intention to use DOCs in searching for information about Iran.

\subsection{Perceived Trust, And Satisfaction}

Chung and Kwon (2009) defined trust as a form of security feeling and an inclination to rely on something or somebody. According to Chen (2006) there are two definitions of perceived trust; first, as a belief, certainty, attitude, or the extent of expectation about someone's trustworthiness; and second, as a behavioral intention or as behavior of reliability, perceived risks and uncertainty. The concept of online trust in information systems has received significant attention in the literature, and has been an important determinant in online environment because of its ability to promote risk required activities in the case of uncertainty (Sullivan \& Kim, 2018). Zhao, Huang, and Su (2019) found out that there is a positive relationship between perceived higher degree of e-trust in sellers and customers' intention to buy online. Kim et al. (2011) also indicated that there is a positive relationship between satisfaction and trust. Additionally, Kim and Peterson (2017) through a meta-analysis of 150 studies revealed that online trust has a significant relationship with intention to purchase, loyalty and satisfaction. They also found out that online trust is a time-consuming concept and longitudinal investigations are required to fully understand its effects. Based on these findings, the following hypothesis will be developed:

H9: Perceived trust of DOCs affects tourists' satisfaction.

\subsection{Attitude toward a Destination, Perceived Usefulness, Satisfaction and Perceived Trust}

According to the TPB, personal belief or attitude is the reason behind the most people's behavioral intentions and even actual behavior (Fishbein \& Ajzen, 1975)). Attitude can be defined as personal disposition to respond favorably or unfavorably to an object, person, institution, and event (Ajzen, 2001). To construct attitude towards DOCs, users involve in a process where they think deliberately, access pertinent information about systems in their mind, evaluate the systems psychologically, and eventually they will be able to announce their constructed attitude (Serenko \& Turel, 2019). The perceived usefulness of a certain IS, leads users to form a positive or negative attitude towards it Chung et al. (2015). The relationship between 'usefulness and attitude' is supported by a number of studies in other contexts (Huh, Kim, \& Law, 2009; Pavlou \& Fygenson, 2006). Moreover, popular websites in travel 
and tourism like Trip Advisor, Lonely planet and Facebook produce significant trust-attitude relationship (Kim \& Peterson, 2017). Most tourists gain information from online destination sources (Govers, Go, \& Kumar, 2007) and trust and satisfaction play an important role in encouraging travelers, because tourism products are intangible and detached spatially and temporally, and travel websites like a channel link potential customer with the destination and tourism products (Chung et al., 2015; Reza et al., 2012). Similarly, Alcántara-Pilar et al. (2018) pointed out that overall satisfaction with web experience influences the user's perception and decision to choose a destination. On the account of above-mentioned studies and because of the important role of DOCs in formation of tourist's attitude and imagination about destination, we propose these hypotheses:

H1O: Perceived usefulness of DOCs positively affects tourists' attitude toward Iran.

H1 1: Satisfaction of DOCs positively affects tourists' attitude toward Iran.

H12: Perceived trust of DOCs positively affects tourists' attitude toward Iran.

\subsection{Attitude towards the Destination and Intention to Visit}

Attitude as a psychological tendency is determined by tourists' evaluation about involvement in a certain behavior (Ajzen, 2001). However, some studies in IS literature ignored and eliminated the role of attitude in the formation of intention (Banerjee, Cronan, \& Jones, 1998; Heijden, 2004; Ryu, Kim, \& Lee, 2009). Recent studies emphasis on the significant role of the attitude to perform a special behavior (Ayeh., Au, \& Law, 2013b; Ghaderi et al., 2018; Jafarkarimi, Saadatdoost, Sim, \& Hee, 2016). Moreover, the relationship between attitude and intention in the travel and tourism literature has been investigated by many researchers. Fri'as, Rodriguez, and Castaneda (2008) indicated that attitude toward the Internet positively affects their intention to use it in the future. In another study, Lee (2009) found out that tourists' attitude affects future tourists' behavior. Also, tourists have more positive attitude toward travel portal websites than companies' websites, because they propose more merchandise options, more convenient applications, and have more value to them (Wen, 2013). Likewise, tourist's attitude is an effective predictor in tourist's decision-making process for traveling to a certain destination (Jalilvand \& Samiei, 2012; Li, Cai, \& Qiu, 2016) and the attitude behind an intention can lead tourists to external behavior (Ajzen, 1991). Hence our last hypothesis will be shaped as:

H13. Tourist's attitude toward Iran has a positive and significant impact on the travel intention.

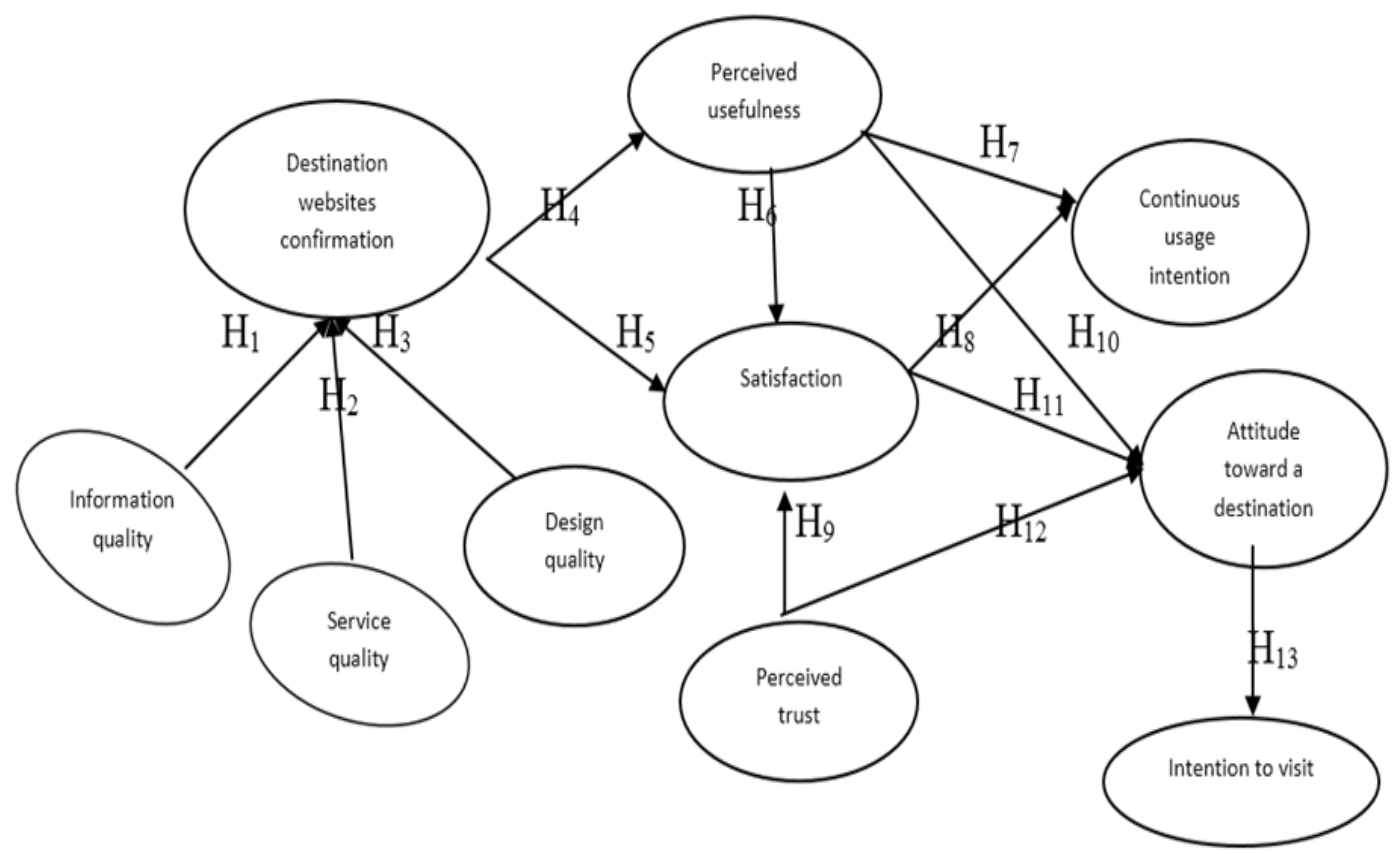

Figure-1. Research proposed model. 


\section{RESEARCH METHODOLOGY}

\subsection{Data Collection, Sampling and Measurement}

The present study was carried out in Tehran, the capital of Iran, in the summer of 2016. The target population was inbound tourists who had traveled to Iran from different countries mainly from Turkey, China, Azerbaijan, Germany, Spain, UK, Austria, the Netherlands, etc. Demographic charateristics of the respondents was provided in Table 1. To collect the required data for the purpose of this research, a survey instrument was developed based on the established measurements from previous literatures.

To measure the information quality, service quality, and design quality, items were developed based on the established constructs from Chung et al. (2015) and Delone and Mclean (2014). Confirmation constructs were adopted from Bhattacherjee (2001) and Chung et al. (2015) while Perceived Usefulness of DOCs constructs were adopted from the following studies (Agag \& El-Masry, 2016; Ayeh. et al., 2013b; Bhattacherjee, 2001; Chung et al., 2015). In addition, satisfaction construct was measured according to Bhattacherjee (2001) and Continuous Usage Intention was adopted from Chung et al. (2015) study.

For Trust, we established measurements from Agag and El-Masry (2016) and (Kim et al., 2011). Constructs of attitude were simulated from the following studies (Agag \& El-Masry, 2016; Ayeh. et al., 2013b; Dolores, 2009; Huh et al., 2009; Jalilvand \& Samiei, 2012). Finally, to investigate the intention to visit Iran, items were adopted form (Chung et al., 2015; Jalilvand \& Samiei, 2012). All items were measured on a five-point Likert scale in a range of between totally disagree (1) and totally agree (5). These 34 items are summarized by each of their constructs in Table 2 .

A pretest survey of 40 inbound tourists was launched to examine the reliability of the questionnaire .After eliminating some items, the final Cronbach's scale for each construct was estimated about 0.75 , more than the minimum acceptable value of 0.7. In total, About 456 questionnaires were distributed in Tehran's international airports, hotels, Tehran historical palaces like Golestan, and Saad Abad, and the National Museum of Iran. All respondents were firstly asked to explain about their experience of using Iranian online contexts, their satisfaction, problems, gaps and strong roles of DOCs in their travel.

This helped them to retrieve the role of the internet in their travel, properly. Normally, those who did not use the internet in their travel (there were few) were eliminated from the research process. Then, the self-reported questionnaire was given and we were in the place to answer any possible inquiries. Finally, 385 valid questionnaires were collected. There were some reasons to choose Tehran. Because Tehran is the main gateway of Iran, and the majority of inbound tourists begin their trips from Tehran to other cities.

\subsection{Data Analysis}

The Structural Equation Modeling technique of Partial Least Squares (Smart PLS) was applied to estimate the theoretical model. Smart PLS regression analysis has several advantages including small sample size, few assumptions about measurement scale and analyzing data without the sensitivity of data normalization (Ahuja \& Thatcher, 2005). In the SEM approach, researchers can evaluate the assumed relationship between observed variables (Gefen, Straub, \& Boudreau, 2000).

Thus, it is possible to evaluate the measurement errors on observed variables as an integral part of the model in order to ensure a more rigorous analysis. Moreover; the Smart PLS is the preferred method when the research objective is theory development and prediction (Hair, Ringle, \& Sarstedt, 2011). In addition, it can measure constructs with no more than two items, so it is less sensitive to measurements. 
Table-1. Demographic characteristic of respondents.

\begin{tabular}{|c|c|c|}
\hline Profile category & Frequency & Percentage (\%) \\
\hline \multicolumn{3}{|l|}{ Gender } \\
\hline Female & 166 & 43.1 \\
\hline Male & 219 & 56.9 \\
\hline \multicolumn{3}{|l|}{ Age } \\
\hline$<=20$ & 17 & 4.4 \\
\hline $20-29$ & 179 & 46.5 \\
\hline $30-39$ & 88 & 22.6 \\
\hline $40-49$ & 60 & 15.6 \\
\hline $50-59$ & 27 & 7 \\
\hline$>=60$ & 14 & 3.6 \\
\hline Total & 385 & 100 \\
\hline \multicolumn{3}{|l|}{ Marital Status } \\
\hline Single & 166 & 43.1 \\
\hline Married & 219 & 56.9 \\
\hline \multicolumn{3}{|l|}{ Region } \\
\hline America and Europe & 334 & 86.8 \\
\hline China & 8 & 2.1 \\
\hline South east Asia & 18 & 4.7 \\
\hline Middle east & 6 & 1.6 \\
\hline Other area & 19 & 4.9 \\
\hline Total & 385 & 100 \\
\hline \multicolumn{3}{|l|}{ Education } \\
\hline High school/Secondary school & 30 & 7.8 \\
\hline Diploma/Associate degree (2 year) & 18 & 4.7 \\
\hline Bachelor & 117 & 30.4 \\
\hline Master & 209 & 54.3 \\
\hline Other & 11 & 2.9 \\
\hline \multicolumn{3}{|l|}{ Daily Internet using } \\
\hline Several time each day & 345 & 89.6 \\
\hline About once a day & 29 & 7.5 \\
\hline Few times a week & 10 & 2.6 \\
\hline Few times a month & 1 & 0.3 \\
\hline
\end{tabular}

\section{RESEARCH FINDINGS}

\subsection{Measurement Model Evaluation}

For content validity of our survey, items were extracted from existing literature, and measurements were implemented by adopting constructs. Convergent validity was established by examining composite reliability (CR), Cronbach's alpha, and the Average Variance Extracted (AVE) (Bhattacherjee \& Sanford, 2006). Cronbach's alpha (greater than 0.7), CR (greater than 0.7) and AVE (greater than 0.5) indicate that all of the constructs used in the model have a significant validity (Bagozzi \& Yi, 1988). Also, the cross loading test implemented and each indicator loadings found to be greater than all of its cross loadings (Chin, 1998).

\subsection{Structure Model and Hypotheses Testing}

$\mathrm{R}^{2}$ (variance prediction) is the main criteria to evaluate the variance explained in the proposed model (Chin, 1998). This index indicates the amount of variance explained by the outer variables (Barclay, Higgins, \& Thompson, 1995). To evaluate the structural model's predictive powers, $\mathrm{R}^{2}$ values of $0.19,0.33$ and 0.67 are described as weak, moderate or substantial (Chin, 1998). 
Table-2. Reliability and cross loadings.

\begin{tabular}{|c|c|c|c|c|c|c|}
\hline Constructs & Measurement items & $\begin{array}{l}\text { Cross } \\
\text { loading }\end{array}$ & T-value & $\mathbf{A}$ & $\mathbf{C R}^{\mathbf{a}}$ & $\mathbf{A V E}^{\mathrm{b}}$ \\
\hline $\begin{array}{l}\text { Information } \\
\text { Quality }\end{array}$ & $\begin{array}{l}\text { 1. The DOCs are fun to read. } \\
\text { 2. The DOCs are full of things to read. } \\
\text { 3. The DOCs are not boring }\end{array}$ & $\begin{array}{l}0.831 \\
0.848 \\
0.841\end{array}$ & $\begin{array}{l}34.664 \\
40.379 \\
39.219\end{array}$ & 0.792 & 0.792 & 0.706 \\
\hline Service Quality & $\begin{array}{l}\text { 1. I can get answers by posting a question } \\
\text { through the DOCs. } \\
\text { 2. I can find the latest information through } \\
\text { these online contexts monthly by } \\
\text { newsletters. } \\
\text { 3. I can get answers to my questions in a } \\
\text { timely manner from these online contexts. } \\
\text { 4. I can get satisfactory email replies from } \\
\text { these online contexts containing all the } \\
\text { information that I need. }\end{array}$ & $\begin{array}{l}0.694 \\
0.809 \\
0.860 \\
0.725\end{array}$ & $\begin{array}{l}15.782 \\
35.654 \\
42.088 \\
21.385\end{array}$ & 0.783 & 0.767 & 0.600 \\
\hline Design Quality & $\begin{array}{l}\text { Generally speaking; } \\
\text { 1. The visual graphic on the DOCs that I } \\
\text { used was user-friendly. } \\
\text { 2. The display colors (or page colors) on the } \\
\text { DOCs were appropriate. } \\
\text { 3. The DOCs that I used were easy to use (I } \\
\text { know how to use them by myself). }\end{array}$ & $\begin{array}{l}0.868 \\
0.894 \\
0.789\end{array}$ & $\begin{array}{l}39.864 \\
53.494 \\
25.255\end{array}$ & 0.808 & 0.809 & 0.725 \\
\hline Confirmation & $\begin{array}{l}\text { 1. User experience on the DOCs is overall } \\
\text { better than expected. } \\
\text { 2. Service level of the DOCs is higher than } \\
\text { expected. } \\
\text { 3. Information (for example, information, } \\
\text { photos...) on the DOCs is better than } \\
\text { expected. }\end{array}$ & $\begin{array}{l}0.842 \\
0.878 \\
0.810\end{array}$ & $\begin{array}{l}42.199 \\
59.620 \\
34.538\end{array}$ & 0.797 & 0.799 & 0.712 \\
\hline Usefulness & $\begin{array}{l}\text { 1. I was able to find a lot of interesting } \\
\text { information on the DOCs I used before } \\
\text { visiting Iran. } \\
\text { 2. The information about my trip provided } \\
\text { by the online contexts was well balanced in } \\
\text { terms of the quality and amount } \\
\text { 3. The information provided by the DOCs } \\
\text { was enriched with the additional links to } \\
\text { related sites. } \\
\text { 4. I was able to find a lot of useful } \\
\text { information on the DOCs that I used before } \\
\text { visiting Iran. }\end{array}$ & $\begin{array}{l}0.833 \\
0.820 \\
0.676 \\
0.865\end{array}$ & $\begin{array}{l}41.969 \\
47.419 \\
18.359 \\
57.910\end{array}$ & 0.814 & 0.816 & 0.643 \\
\hline Satisfaction & $\begin{array}{l}\text { 1. After using DOCs, I am... very } \\
\text { dissatisfied vs. very satisfied } \\
\text { 2. After using the DOCs, I am... very } \\
\text { displeased vs. very pleased. } \\
\text { 3. After using the DOCs, I am feeling } \\
\text { terrible vs. delighted. }\end{array}$ & $\begin{array}{l}0.904 \\
0.919 \\
0.870\end{array}$ & $\begin{array}{l}74.978 \\
83.418 \\
58.814\end{array}$ & 0.880 & 0.880 & 0.806 \\
\hline $\begin{array}{l}\text { Continued } \\
\text { Usage } \\
\text { Intention }\end{array}$ & $\begin{array}{l}\text { 1. I will use these DOCs on a regular basis } \\
\text { in the future. } \\
\text { 2. I will frequently use these DOCs in the } \\
\text { future. } \\
\text { 3. I will continue to use these DOCs. } \\
\text { 4. I will strongly recommend others to use } \\
\text { these DOCs. }\end{array}$ & $\begin{array}{l}0.886 \\
0.872 \\
0.848 \\
0.787\end{array}$ & $\begin{array}{l}56.628 \\
50.824 \\
36.458 \\
40.623\end{array}$ & 0.872 & 0.863 & 0.721 \\
\hline Trust & $\begin{array}{l}\text { 1. The DOCs that I used are reliable. } \\
\text { 2. The DOCs that I used are trustworthy. } \\
\text { 3. The DOCs that I used have integrity. }\end{array}$ & $\begin{array}{l}0.906 \\
0.925 \\
0.782 \\
\end{array}$ & $\begin{array}{l}68.690 \\
88.534 \\
26.544 \\
\end{array}$ & 0.844 & 0.852 & 0.762 \\
\hline $\begin{array}{l}\text { Attitude } \\
\text { Toward a } \\
\text { Destination }\end{array}$ & $\begin{array}{l}\text { 1. After using the DOCs, I have a Good vs. } \\
\text { Bad attitude toward travel to Iran. } \\
\text { 2. After using the DOCs, I have a Pleasant } \\
\text { vs. Unpleasant attitude toward travel to } \\
\text { Iran. } \\
\text { 3. After using the DOCs, I have a Negative } \\
\text { vs. Positive attitude toward travel to Iran. } \\
\text { After using the DOCs, I think travel to Iran }\end{array}$ & $\begin{array}{l}0.878 \\
0.914 \\
0.886 \\
0.810\end{array}$ & $\begin{array}{l}55.654 \\
84.959 \\
62.473 \\
34.415\end{array}$ & 0.895 & 0.897 & 0.762 \\
\hline
\end{tabular}




\begin{tabular}{l|l|c|c|c|c}
\hline & is a Foolish vs. Wise decision. & & & \\
\hline \multirow{3}{*}{$\begin{array}{l}\text { Intention to } \\
\text { Visit }\end{array}$} & $\begin{array}{l}\text { 1. I would visit Iran rather than any other } \\
\text { tourism destination. }\end{array}$ & 0.610 & 12.931 & \\
$\begin{array}{l}\text { 2. After using the DOCs, I planned to visit } \\
\text { Iran. } \\
\text { 3. After using the DOCs, I determined to } \\
\text { visit Iran in the future. }\end{array}$ & 0.895 & 54.767 & 0.746 \\
\end{tabular}

The discriminant validity of the ten constructs was examined through the Fornell and Larcker test. A latent construct should share variance with its defined indicators more than any other latent constructs (Fornell \& Larcker, 1981). As can be seen in Table 3 all latent constructs meet this important prerequisite.

Table-3. Correlations for the constructs and the square root of AVE.

\begin{tabular}{|c|c|c|c|c|c|c|c|c|c|c|}
\hline Constructs & 1 & 2 & 3 & 4 & 5 & 6 & 7 & 8 & 9 & 10 \\
\hline $\begin{array}{c}\text { Attitude } \\
\text { toward a } \\
\text { destination }\end{array}$ & $0.873^{*}$ & & & & & & & & & \\
\hline Confirmation & 0.233 & $0.844^{*}$ & & & & & & & & \\
\hline $\begin{array}{c}\text { Continuous } \\
\text { usage } \\
\text { intention }\end{array}$ & 0.383 & 0.393 & $0.849^{*}$ & & & & & & & \\
\hline Design quality & 0.27 & 0.394 & 0.471 & $0.851^{*}$ & & & & & & \\
\hline $\begin{array}{c}\text { Information } \\
\text { quality }\end{array}$ & 0.338 & 0.46 & 0.496 & 0.561 & $0.840^{*}$ & & & & & \\
\hline $\begin{array}{c}\text { Intention to } \\
\text { visit }\end{array}$ & 0.548 & 0.09 & 0.239 & 0.125 & 0.157 & $0.822^{*}$ & & & & \\
\hline Satisfaction & 0.366 & 0.463 & 0.557 & 0.558 & 0.562 & 0.243 & $0.898^{*}$ & & & \\
\hline Service quality & 0.237 & 0.411 & 0.361 & 0.419 & 0.438 & 0.067 & 0.539 & $0.775^{*}$ & & \\
\hline Trust & 0.332 & 0.25 & 0.381 & 0.433 & 0.358 & 0.263 & 0.46 & 0.347 & $0.873^{*}$ & \\
\hline Usefulness & 0.35 & 0.486 & 0.503 & 0.476 & 0.573 & 0.224 & 0.587 & 0.433 & 0.394 & $0.802^{*}$ \\
\hline
\end{tabular}

As well as, Stone-Geissler's $\left(\mathrm{Q}^{2}\right)$ Test is another assessment of the structural model which concerns the model's capability of prediction (Geisser \& Eddy, 1979; Stone, 1974). $Q^{2}$ test has been developed to assess the predictive validity of the exogenous latent variables. Values of $Q^{2}$ greater than zero suggest that the exogenous constructs have predictive relevance, while values below zero imply a lack of predictive relevance (Chin, 1998). All $\mathrm{Q}^{2}$ values significantly ranged above zero, thus demonstrating the exogenous constructs high predictive power. $\mathrm{R}^{2}$ and $\mathrm{Q}^{2}$ values for all measurements are presented in Table 4.

Table-4. The explained variance $\left(\mathrm{R}^{2}\right)$ and the prediction relevance $\left(\mathrm{Q}^{2}\right)$ test.

\begin{tabular}{c|c|c}
\hline Endogenous construct Explained & Variance Prediction $\left(\mathbf{R}^{2}\right)$ & $\begin{array}{c}\text { Relevance Intention } \\
\left(\mathbf{Q}^{2}\right)\end{array}$ \\
\hline Attitude toward a destination & 0.187 & 0.138 \\
\hline Confirmation & 0.279 & 0.195 \\
\hline Continuous usage intention & 0.358 & 0.24 \\
\hline Intention to visit & 0.301 & 0.198 \\
\hline Satisfaction & 0.441 & 0.352 \\
\hline Usefulness & 0.237 & 0.149 \\
\hline
\end{tabular}

\subsection{Hypotheses Testing}

Through the bootstrapping technique we calculated the t-statistics and path estimates for hypotheses. The size of the bootstrapping sample used in the Smart PLS analyses was 500. These results (as presented in Figure 2, and Table 5) show the strong causal relationship between all hypotheses, and all paths (Hypothesis 1-13) were 
supported. Hypotheses 1,2 , and 3 indicate that Iranian online contexts confirmation is significantly influenced by information quality $(\beta=0.281, \mathrm{t}=4.552, \mathrm{p}<0.01)$, service quality $(\beta=0.229, \mathrm{t}=4.860, \mathrm{p}<0.01)$, and design quality $(\beta=0.140, \mathrm{t}=2.291, \mathrm{p}<0.05)$. Regarding the $\mathrm{H} 4$ and $\mathrm{H} 5$; analyses show that websites' confirmation positively affects the perceived usefulness $(\beta=0.486, \mathrm{t}=11.235, \mathrm{p}<0.01)$, and satisfaction $(\beta=0.213, \mathrm{t}=4.425, \mathrm{p}$ $<$ 0.01). Moreover, hypothesis 6 examines the relationship between perceived usefulness and satisfaction of the DOCs and it is positively approved $(\beta=0.383, \mathrm{t}=7.743, \mathrm{p}<0.01)$. Likewise, $\mathrm{H} 7$ and $\mathrm{H} 8$ which assume direct positive relationship between DOCs continuous usage intention and perceived usefulness $(\beta=0.269, \mathrm{t}=4.291, \mathrm{p}<$ $0.01)$ and satisfaction $(\beta=0.399, \mathrm{t}=7.142, \mathrm{p}<0.01)$ have been verified respectively.

In support of hypothesis 9; Trust $(\beta=0.256, \mathrm{t}=5.402, \mathrm{p}<0.01)$ positively and directly impacts the satisfaction. Moreover, Perceived usefulness (H10) has positive impacts on the attitude toward a destination ( $\beta=$ $0.172, \mathrm{t}=2.894, \mathrm{p}<0.01)$. Hypotheses 11 and 12 consider the relationship between satisfaction and trust on attitude toward a destination, which both of them are found to have significant positive effects on the attitude ( $\beta=$ $0.182, \mathrm{t}=2.522, \mathrm{p}<0.05),(\beta=0.181, \mathrm{t}=2.877, \mathrm{p}<0.01)$ subsequently.

Finally, the most powerful relationship belongs to hypothesis 13 which asserts that attitude toward a destination is extracted to be an important antecedent of intention to visit a destination $(\beta=0.548, t=15.062, \mathrm{p}<$ $0.01)$.

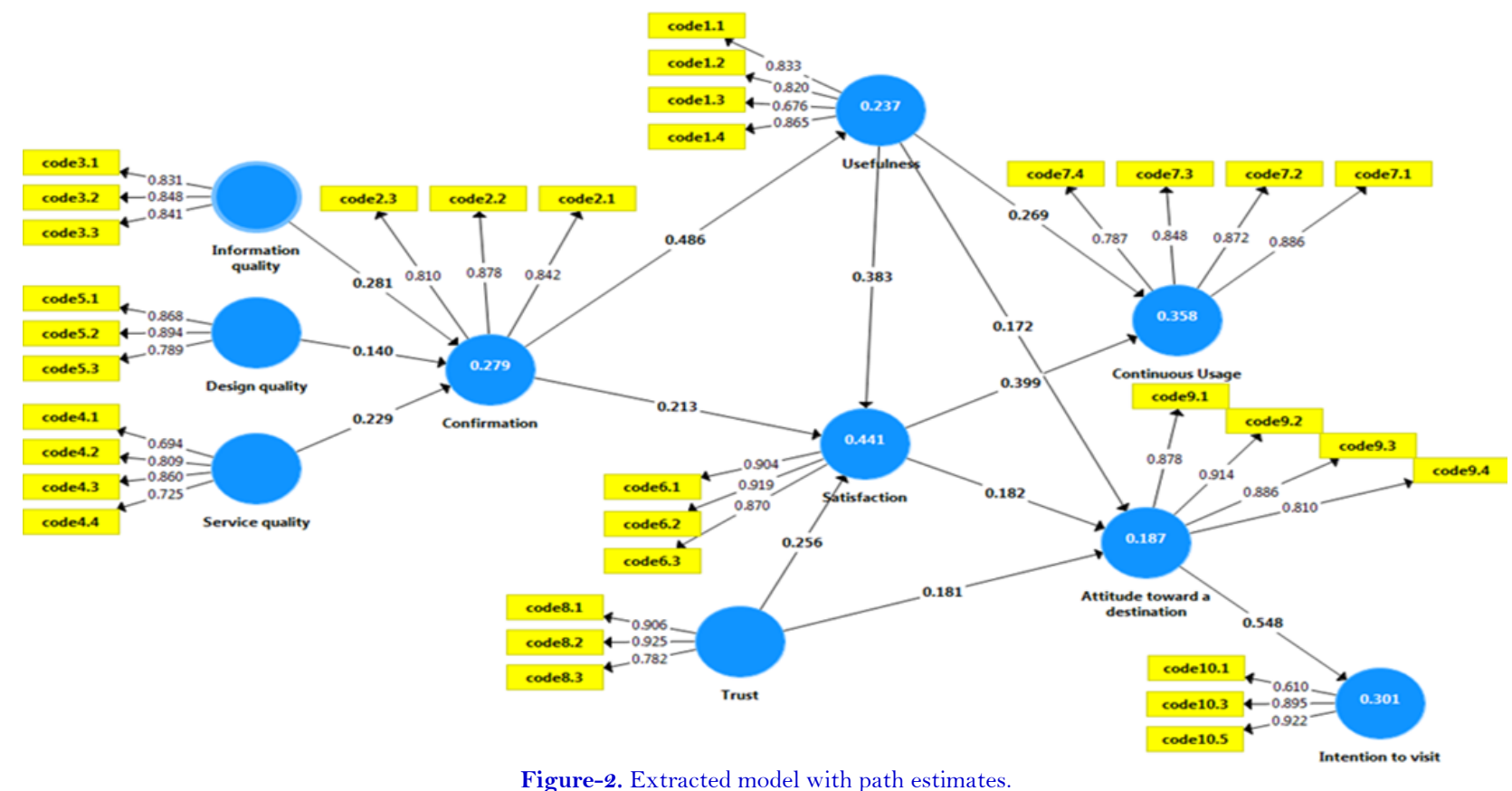

Table-5. The results of the hypothesis testing - applied for single-platform users

\begin{tabular}{|c|c|c|c|c|}
\hline Hypothesis & Path & Estimates & t-value & Results \\
\hline Hypothesis 1 & Information $\longrightarrow$ Confirmation & 0.281 & 4.552 & Supported \\
\hline Hypothesis 2 & Service quality $\longrightarrow$ & 0.229 & 4.86 & Supported \\
\hline Hypothesis 3 & Design $\longrightarrow$ Confirmation & 0.14 & 2.291 & Supported \\
\hline Hypothesis 4 & Confirmation $\longrightarrow$ Usefulness & 0.486 & 11.235 & Supported \\
\hline Hypothesis 5 & Confirmation $\longrightarrow$ Satisfaction & 0.213 & 4.425 & Supported \\
\hline Hypothesis 6 & Usefulness $\longrightarrow$ Satisfaction & 0.383 & 7.743 & Supported \\
\hline Hypothesis 7 & Usefulness $\longrightarrow$ Continuous usage & 0.269 & 4.291 & Supported \\
\hline Hypothesis 8 & Satisfaction $\longrightarrow$ Continuous usage & 0.399 & 7.142 & Supported \\
\hline Hypothesis 9 & Trust $\longrightarrow$ Satisfaction & 0.256 & 5.402 & Supported \\
\hline Hypothesis 10 & Usefulnes $\longrightarrow$ Attitude & 0.181 & 2.877 & Supported \\
\hline Hypothesis 11 & Satisfaction $\longrightarrow$ Attitude & 0.182 & 2.522 & Supported \\
\hline Hypothesis 14 & Trust $\longrightarrow$ Attitude & 0.172 & 2.894 & Supported \\
\hline Hypothesis 13 & Intention & 0.548 & 15.062 & Supported \\
\hline
\end{tabular}




\section{DISCUSSIONS AND CONCLUSION}

In this study, we wanted to show how travelling to a certain destination could be influenced by online travel contexts, system quality, tourists' satisfaction, and tourists' intention to visit a destination. We applied insights from the Delone and Mclean's model, IS success model and the theory of planned behavior to identify a process which sheds light on some facts about destination online presence and tourists' intention to visit a particular destination. As the first, second, and third hypotheses showed, information quality, service quality and design quality of DOCs positively affect tourists' confirmation. This implies that tourists not only expect obtaining quality and useful information from online platforms and sources, but supported services and even the design of this information (for example, display colors, user-friendly graphics, etc.) are important stimuli to continue using DOCs. Users, nowadays, are demanding more customized information and services to fulfill their needs. This finding is consistent with the results of previous studies in other parts of the world that the three factor qualities affect user confirmation (Chung et al., 2015; Lai et al., 2016; Lee \& Chung, 2009). However, our findings revealed that information and service quality of the DOCs have stronger positive relationship with the confirmation, while in previous studies, design quality was stronger than service quality (Al-Qeisi, Dennis, Alamanos, \& Jayawardhena, 2014; Chung et al., 2015; Petter \& McLean, 2009; Roca, Chiu, \& Martínez, 2006). One possible justification could be that the majority of online contexts have a unique and standard style and design, and almost all tourists use these popular platforms frequently not only for travelling to Iran, but in their previous travels. Therefore, for experienced users, design quality is no longer an issue, and service quality comes as first priority for travelers than the design quality (Zhou, Lu, \& Wang, 2006).

On the account of the hypotheses $4 \& 5$, our investigations indicate a strong positive association between tourists' confirmation of the DOCs and perceived usefulness and satisfaction. By inspiration of previous studies and based on the IS success model, and ECM, we examined the effects of the DOCs on the satisfaction and perceived usefulness (Alcántara-Pilar et al., 2018; Chung et al., 2015; Kim et al., 2011; Lin, Wu, \& Tsai, 2005; Roca et al., 2006; Shin, Shin, Choo, \& Beom, 2011; Thong et al., 2006). According to our findings; it seems that perceived usefulness of DOCs predominantly depends on the confirmation of the information, service and design quality. Therefore, it can be said that the more qualified DOCs in a destination, the more destination online presence will be perceived usefulness. Depending on the types of customers, DOCs produce a continuum of useful and diverse information through user-friendly systems to invoke travelers' interests and encourage them to stay for longer time on the website.

Hypotheses six and seven also showed that perceived usefulness of DOCs positively affects user's satisfaction and the continuous intention to use DOCs in gathering information. Additionally, hypothesis eight confirmed that satisfaction positively affects the continuous intention to use DOCs. Our analyses reveal that user's perceptions and satisfaction determine browsing behavior, as satisfied users will continue usage of the DOCs in their travel (Chung et al., 2015). As Kim and Peterson (2017) through a meta-analysis of online trust indicated; the future of B2C ecommerce would be foggy without e-trust, and highlighted the significance of trust to online contexts. Our nine hypothesis also confirmed that perceived trust of DOCs affects tourists' satisfaction. In comparison to other studies which investigated the effects of trust directly on the intention (Kim \& Peterson, 2017; Oliveira, Alhinho, Rita, \& Dhillon, 2017; Sullivan \& Kim, 2018; Zhao et al., 2019), our study is amongst the first studies that apply online trust to the ECM and IS success model in the tourism literature, due to its significance effects on DOCs. Our findings support previous studies (Agag \& El-Masry, 2016; Bonsón Ponte, Carvajal-Trujillo, \& Escobar-Rodríguez, 2015; Wang, Law, Guillet, Hung, \& Fong, 2015) which claimed that perceived trust positively impacts the satisfaction and attitude. It is apparent that tourists need to find DOCs trustworthy before probing the web, and credible data is pre-requisite of their satisfaction (Kim \& Peterson, 2017).

On the account of hypotheses 10,11 and 12, perceived usefulness of DOCs, satisfaction of DOCs and perceived trust of DOCs positively affect international tourists' attitude towards Iran. These are important lessons for 
practitioners in Iran since the country suffers from particular political issues, isolated connections, and negative connotations (Ghaderi et al., 2018). DOCs can be suggested as an appropriate applications and alternatives to offset the narratives of other media which spread unwelcoming and inappropriate depictions of the country and Iranian people (Ghaderi et al., 2018).

Finally, hypothesis 13, supports this claim that tourist's attitude toward Iran has a positive and significant impact on the travel intention. However, DOCs are strongly able to change tourists' attitude (Park, Kim, \& Ryu, 2019) and attitude is a key motivation of behavioral change (Kimelfeld \& Watt, 2001) there are a few studies in tourism literature tried to directly illuminate the role of online attitude in making intention to visit a destination (Ayeh. et al., 2013b; Ghaderi et al., 2018; Park et al., 2019; Reza et al., 2012). Our findings highlight the role of online attitude as a strong predictor on intention to visit Iran.

\subsection{Research Contribution}

This research has both practical and theoretical contributions. From the theoretical perspective, our study showed the positive and direct relationship between three quality factors and confirmation which proved the practicability of the Delone and Mclean's model both for investigating the effects of one IS and DOCs. Moreover, by inspiration of Chung et al. (2015); Lee and Chung (2009) and Roca et al. (2006) which applied design quality instead of system quality in their proposed model, our study found positive relationship between design quality and DOCs confirmation. Therefore applying this variable in further studies will be so helpful to deepen its effects on tourism destinations.

In his study, Ambalov (2018) found stronger relationship between confirmation and satisfaction than confirmation and perceived usefulness, on the contrary, our results show an adverse relationship for DOCs (confirmation-perceived usefulness stronger than confirmation-satisfaction path). Likewise; due to inconsistence and insignificance relationship between perceived usefulness and satisfaction acknowledged by empirical studies, Bhattacherjee and Lin (2014) eliminated this relationship in the updated ECM model. However, our findings confirm a strong positive relationship between two constructs in destination online contexts (DOCs). This relationship accentuates that any combination of customers behavioral theories should keep the specialty of tourists online behavior in view.

Compared to the previous studies in the ECM, IS success model, and TPB, which neglected the tourists' browsing behavior and their attitude towards DOCs, our study found that online attitude towards a destination could be introduced as an alternative and representative construct which strongly mediates the effects of DOCs on visit intention. Because, DOCs act as a window enabling tourists to browse and compare all the facilities named as destination possibilities, and it helps them to shape their image of the destination with variety of feelings, thoughts and desires (Alcántara-Pilar et al., 2018). Additionally, online attitude is a changeable concept which depends on the online platforms. For example (Casado-díaz et al., 2018) found out that post-attitude, attitude change and intention to buy online travel products are significantly higher in Twitter in comparison to Trip Advisor. Therefore, application of this variable would be more relevant to measure the real effects of the ICT in tourism studies. According to our findings; online attitude has a strong direct relationship with intention to visit a destination, and the more positive attitudes are toward a destination, the stronger desire and intention to travel.

\subsection{Managerial Implications}

A number of managerial recommendations could be concluded from the present work. Firstly, our proposed model provides a summary of a process which strongly affects users. Marketing practitioners should notice that not only all variables in the model play an important role to satisfy users of their online context, but well qualified online contexts generally affect user's perception toward a destination (Nielsen, 2000). Furthermore, any adoption and simulation of the IS models should consider the specialty of the tourist's online behavior, as they are using 
many online platforms and their behavior can be determined with different effect paths and priorities than other fields. DOCs managers in the destination should notice that the quality of the service and information being provided to users are strong predictor in confirming the DOCs qualities, which in turn has great impacts on the satisfaction, perceived DOCs usefulness and their prospective behavior. Moreover, design quality is another antecedents of confirming destination contexts as well-established sources. Although external popular tourism websites have their own design and standards which could not be managed easily, internal contexts should enhance their design quality(color, the quality of the photos, videos, navigation, graphic, and making user-friendly contexts) and always get feedbacks from users to improve the weak design points (Reza et al., 2012).

Tourists' satisfaction of the destination services is being reflected through their blogs, pages, and comments on the popular websites like Trip Advisor. To manage external online contexts, all tourism players in the destination should work on a positive image of themselves in the tourists' mind, so that travelers write and put constructive information about their experiences on the web. In addition, measuring traveler's online satisfaction, checking their reviews, trying to reduce the dissatisfaction mentioned in these websites would be so beneficial. Finally, tourism administrators should manage the destination online presence to introduce an integrated image of Iran in the internet (Lee et al., 2019). In this way, they can set some standards to help firms and travel unit so as to provide professional online platforms.

\subsection{Research Limitations and Suggestions for Future Studies}

Any study should be considered with its limitations. First of all, due to the geographical heterogeneity in Iran, we could not access travelers from neighboring countries who visit Iran regularly in the year for medical, trade, and religious purposes. However, this reduces the mediate effects of the familiarity toward destination on the results (Chaulagain, Wiitala, \& Fu, 2019) and future studies can focus on each type of these visitors and compare their online attitude altogether. Moreover, we just investigated the whole effects of DOCs on tourist's attitude before visiting Iran, as well as, we just tried to highlight the role of online contexts in shaping attitude, but future studies could concentrate more on attitude during and after the trip.

Funding: This study received no specific financial support.

Competing Interests: The authors declare that they have no competing interests.

Acknowledgement: All authors contributed equally to the conception and design of the study.

\section{REFERENCES}

Agag, G., \& El-Masry, A. A. (2016). Understanding consumer intention to participate in online travel community and effects on consumer intention to purchase travel online and WOM. Computers in Human Behavior, 60(C), 97-111. Available at: https://doi.org/10.1016/j.chb.2016.02.038.

Agarwal, R., \& Karahanna, E. (2000). Time flies when you're having fun: Cognitive absorption and beliefs about information technology usage. MIS Quarterly, 24(4), 665. Available at: https://doi.org/10.2307/3250951.

Ahuja, M. K., \& Thatcher, J. B. (2005). Moving beyond intentions and toward the theory of trying: Effects of work environment and gender on post-adoption information technology use. MIS Quarterly, 29(3), 427-459. Available at: https://doi.org/10.1016/j.chb.2010.07.007.

Ajzen, I. (1991). The theory of planned behavior. Organizational Behavior and Human Decision Processes, 50(2), 179-211. Available at: https://doi.org/10.1016/0749-5978(91)90020-T.

Ajzen, I. (2001). Nature and operation of attitudes. Annual Review of Psychology, 52(1), 27. Available at: https://doi.org/10.1146/annurev.psych.52.1.27.

Al-Qeisi, K., Dennis, C., Alamanos, E., \& Jayawardhena, C. (2014). Website design quality and usage behavior: Unified theory of acceptance and use of technology. Journal of Business Research, 67(11), 2282-2290. Available at: https://doi.org/10.1016/j.jbusres.2014.06.016. 
Alcántara-Pilar, J. M., Blanco-Encomienda, F. J., Armenski, T., \& Del Barrio-García, S. (2018). The antecedent role of online satisfaction, perceived risk online, and perceived website usability on the affect towards travel destinations. Journal of Destination Marketing and Management, 9(9), 20-35. Available at: https://doi.org/10.1016/j.jdmm.2017.09.005.

Ambalov, I. A. (2018). A meta-analysis of IT continuance: An evaluation of the expectation-confirmation model. Telematics and Informatics, 35(6), 1561-1571. Available at: https://doi.org/10.1016/j.tele.2018.03.016.

Ayeh, J. K., Au, N., \& Law, R. (2013a). Do we believe in trip advisor?” Examining credibility perceptions and online travelers' attitude toward using user-generated content. Journal of Travel Research, 52(4), 437-452. Available at: https://doi.org/10.1177/0047287512475217.

Ayeh., J. K., Au, N., \& Law, R. (2013b). Predicting the intention to use consumer-generated media for travel planning. Tourism Management, 35(C), 132-143. Available at: https://doi.org/10.1016/j.tourman.2012.06.010.

Bagozzi, R. P., \& Yi, Y. (1988). On the evaluation of structural equation models. Journal of the Academy of Marketing Science, 16(1), 74-94.

Baloglu, S., Henthorne, T. L., \& Sahin, S. (2014). Destination image and brand personality of Jamaica: A model of tourist behavior. Journal of Travel \& Tourism Marketing, 31(8), 1057-1070. Available at: https://doi.org/10.1080/10548408.2014.892468.

Banerjee, D., Cronan, T. P., \& Jones, T. W. (1998). Modeling IT ethics: A study in situational ethics. MIS Quarterly, 22(1), 31-60. Available at: https://doi.org/10.2307/249677.

Barclay, D., Higgins, C., \& Thompson, R. (1995). The partial least squares (PLS) approach to causal modeling: Personal computer adoption and use as an illustration. Technology Studies, 2(2), 285-309.

Beldona, S. (2005). Cohort analysis of online travel information search behavior: 1995-2000. Journal of Travel Research, 44(2), 135-142. Available at: https://doi.org/10.1177/0047287505278995

Bhattacherjee, A. (2001). Understanding information systems continuance: An expectation-confirmation model. Anol Bhattacherjee Source: MIS Quarterly, 25(3), 351-370. Available at: https://doi.org/10.2307/3250921.

Bhattacherjee, A., \& Premkumar, G. (2004). Understanding changes in belief and attitude toward information technology usage: A theoretical model and longitudinal test. MIS Quarterly, 28(2), 229-254. Available at: https://doi.org/10.2307/25148634

Bhattacherjee, A., \& Sanford, C. C. (2006). Influence processes for information technology acceptance: an elaboration liklihood model. Management Information Systems Quarterly, 30(4), 805-825. Available at: https://doi.org/10.2307/25148755.

Bhattacherjee, A., \& Barfar, A. (2011). Information technology continuance research: Current state and future directions. Asia Pacific Journal of Information Systems, 21(2), 1-18. Available at: https://doi.org/10.2307/325092 1.

Bhattacherjee, A., \& Hikmet, N. (2008). Reconceptualizing organizational support and its effect on information technology usage: Evidence from the health care sector. Journal of Computer Information Systems, 48(4), 69-76.

Bhattacherjee, A., \& Lin, C. (2014). Research article a unified model of it continuance: Three complementary perspectives and crossover effects. (july 2013). 1-10. Available at: https://doi.org/10.1057/ejis.2013.36.

Bonsón Ponte, E., Carvajal-Trujillo, E., \& Escobar-Rodríguez, T. (2015). Influence of trust and perceived value on the intention to purchase travel online: Integrating the effects of assurance on trust antecedents. Tourism Management, 47(C), 286302. Available at: https://doi.org/10.1016/j.tourman.2014.10.009

Bronner, F., \& Hoog, R. (2016). Travel websites: Changing visits, evaluations and posts. Annals of Tourism Research, 57, 94-1 12. Available at: https://doi.org/10.1016/j.annals.2015.12.012.

Buhalis, D., \& Law, R. (2008). Progress in information technology and tourism management: 20 years on and 10 years after the Internet-the state of etourism research. Tourism Management, 29(4), 609-623. Available at: https://doi.org/10.1016/j.tourman.2008.01.005.

Casado-díaz, A. B., Andreu, L., Beckmann, S. C., Miller, C., Andreu, L., Beckmann, S. C., \& Andreu, L. (2018). Current issues in tourism negative online reviews and webcare strategies in social media: Effects on hotel attitude and booking 
intentions e ff ects on hotel attitude and booking intentions. Current Issues in Tourism, O(0), 1-5. Available at: https://doi.org/10.1080/13683500.2018.1546675.

Chaulagain, S., Wiitala, J., \& Fu, X. (2019). The impact of country image and destination image on US touris ts' travel intention.

Journal of Destination Marketing and Management, 12(1), 1-11. Available at: https://doi.org/10.1016/j.jdmm.2019.01.005.

Chen, C. (2006). Identifying significant factors influencing consumer trust in an online travel site. Information Technology \& Tourism, 8(3-4), 197-2 14. Available at: https://doi.org/10.3727/109830506778690849.

Chin, W. W. (1998). The partial least squares approach to structural equation modeling. Modern Methods for Business Research, 295(2), 295-336.

Choi, M., Law, R., \& Heo, C. Y. (2016). Shopping destinations and trust-tourist attitudes: Scale development and validation. Tourism Management, 54(C), 490-501. Available at: https://doi.org/10.1016/j.tourman.2016.01.005.

Chung, N., \& Kwon, S. J. (2009). Effect of trust level on mobile banking satisfaction: a multi-group analysis of information system success instruments. Behaviour $\&$ Information Technology, 28(6), 549-562. Available at: https://doi.org/10.1080/01449290802506562.

Chung, N., Lee, H., Lee, S.-J., \& Koo, C. (2015). The influence of tourism website on tourists' behavior to determine destination selection:: A case study of creative economy in Korea. Technological Forecasting and Social Change, 96(1), 130-143. Available at: https://doi.org/10.1016/j.techfore.2015.03.004.

Davis, F. D. (1989). Perceived usefulness, perceived ease of use, and user acceptance of information technology. MIS Quarterly, 13(3), 319. Available at: https://doi.org/10.2307/249008.

Davis, F. D., Bagozzi, R. P., \& Warshaw, P. R. (1989). User acceptance of computer technology. Journal of Management Science, 35(8), 982-1003.

DeLone, W. H., \& McLean, E. R. (1992). Information systems success: The quest for the dependent variable. Information Systems Research, 3(1), 60-95. Available at: https://doi.org/10.1287/isre.3.1.60.

Delone, W. H., \& Mclean, E. R. (2014). The DeLone and McLean model of information systems success: A ten-year update. Journal of Management Information Systems, $1222, \quad 8-30 . \quad$ Available at: https://doi.org/10.1080/0742 1222.2003.1 1045748.

Dolores, J. A. C. (2009). Article information.

Fishbein, M., \& Ajzen, I. (1975). Belief, attitude, intention, and behavior: An introduction to theory and research (pp. 1-18). Reading, MA: Addison-Wesley.

Fornell, C., \& Larcker, D. F. (1981). Evaluating structural equation models with unobservable variables and measurement error. Journal of Marketing Research, 18(1), 39-50.

Frı'as, D. M., Rodrıguez, M. A., \& Castaneda, J. A. (2008). Internet vs. travel agencies on pre-visit destination image formation: An information processing view. Tourism Management, 29(1), 163-179. Available at: https://doi.org/10.1016/j.tourman.2007.02.020.

Gang, R., \& Taeho, H. (2018). Examining the relationship between speci fi c negative emotions and the perceived helpfulness of online reviews. Retrieved from: https://doi.org/10.1016/j.ipm.2018.04.003.

Gefen, D., Straub, D. W., \& Boudreau, M. C. (2000). Structural equation modeling and regression: Guidelines for research practice. Communications of the Association for Information Systems, 4(7), 76. Available at: https://doi.org/10.1.1.25.781.

Geisser, S., \& Eddy, W. F. (1979). A predictive approach to model selection. Journal of the American Statistical Association, 74(365), 153-160.

Ghaderi, Z., Hatamifar, P., \& Henderson, J. C. (2018). Destination selection by smart tourists: The case of Isfahan, Iran. Asia Pacific Journal of Tourism Research, 23(4), 385-394. Available at: https://doi.org/10.1080/10941665.2018.1444650.

Govers, R., Go, F. M., \& Kumar, K. (2007). Promoting tourism destination image. Journal of Travel Research, 46(1), 15-23. Available at: https://doi.org/10.1177/0047287507302374. 
Hair, J. F., Ringle, C. M., \& Sarstedt, M. (2011). PLS-SEM: Indeed a silver bullet. Journal of Marketing theory and Practice, 19(2), 139-152. Available at: https://doi.org/10.2753/MTP1069-6679190202.

Heijden, H. V. D. (2004). Management information systems research center, University of Minnesota. MIS Quarterly, 28(4), 695704.

Ho, L.-A., Kuo, T.-H., \& Lin, B. (2012). The mediating effect of website quality on Internet searching behavior. Computers in Human Behavior, 28(3), 840-848. Available at: https://doi.org/10.1016/j.chb.2011.11.024.

Huh, H. J., Kim, T. T., \& Law, R. (2009). A comparison of competing theoretical models for understanding acceptance behavior of information systems in upscale hotels. International Journal of Hospitality Management, 28(1), 121-134. Available at: https://doi.org/10.1016/j.ijhm.2008.06.004.

Jafarkarimi, H., Saadatdoost, R., Sim, A. T. H., \& Hee, J. M. (2016). Behavioral intention in social networking sites ethical dilemmas: An extended model based on theory of planned behavior. Computers in Human Behavior, 62, 545-561. Available at: https://doi.org/10.1016/j.chb.2016.04.024.

Jalilvand, M. R., \& Samiei, N. (2012). The impact of electronic word of mouth on a tourism destination choice: Testing the theory of planned behavior (TPB). Internet Research, 22(5), 591-612. Available at: https://doi.org/10.1108/10662241211271563.

Jung, T. (2009). Assessing low-cost carrier eairline system success. In Information and Communication Technologies in Tourism 2009. Vienna: Springer.

Karahanna, E., Straub, D., \& Chervany, N. (1999). Information technology adoption across time: A cross-sectional comparison of pre-adoption and post-adoption beliefs. MIS Quarterly, 23(2), 183-213.

Kim, M. J., Chung, N., \& Lee, C. K. (2011). The effect of perceived trust on electronic commerce: Shopping online for tourism products and services in South Korea. Tourism Management, 32(2), 256-265. Available at: https://doi.org/10.1016/j.tourman.2010.01.011.

Kim, Y., \& Peterson, R. A. (2017). A meta-analysis of online trust relationships in E-commerce. Journal of Interactive Marketing, 38, 44-54. Available at: https://doi.org/10.1016/j.intmar.2017.01.001.

Kimelfeld, Y. M., \& Watt, J. H. (2001). The pragmatic value of on-line transactional advertising: A predictor of purchase intention. Journal of Marketing Communications, 7(3), 137-157.

Lai, H.-M., Chen, C.-P., \& Chang, Y.-F. (2016). Expectation-confirmation model of information system continuance: A metaanalysis. International Journal of Educational and Pedagogical Sciences, 10(7), 2325-2330.

Lam, S. Y., Shankar, V., Erramilli, M. K., \& Murthy, B. (2004). Customer value, satisfaction, loyalty, and switching cos ts: An iilustration from a business-to-business service context. Journal of the Academy of Marketing Science, 32(3), $293-311$. Available at: https://doi.org/10.1177/0092070304263330.

Lee, T. H. (2009). A structural model to examine how destination image, attitude, and motivation affect the future behavior of tourists. Leisure Sciences, 3 1(3), 215-236. Available at: https://doi.org/10.1080/01490400902837787.

Lee, K. C., \& Chung, N. (2009). Understanding factors affecting trust in and satisfaction with mobile banking in Korea: A modified DeLone and McLean's model perspective. Interacting with Computers, 21(5-6), 385-392. Available at: https://doi.org/10.1016/j.intcom.2009.06.004.

Lee, H., Chung, N., \& Nam, Y. (2019). Do online information sources really make tourists visit more diverse places ?: Based on the social networking analysis. Information Processing and Management, 56(4), 1376-1390. Available at: https://doi.org/10.1016/j.ipm.2018.01.005.

Li, M., Cai, L. A., \& Qiu, S. (2016). A value, affective attitude, and tourist behavioral intention model. Journal of China Tourism Research, 12(2), 179-195. Available at: https://doi.org/10.1080/19388160.2016.1225620.

Limayem, M., \& Cheung, C. M. (2008). Understanding information systems continuance: The case of Internet-based learning technologies. Information \& Management, 45(4), 227-232. Available at: https://doi.org/10.1016/j.im.2008.02.005.

Lin, C. S., Wu, S., \& Tsai, R. J. (2005). Integrating perceived playfulness into expectation-confirmation model for web portal context. Information \& Management, 42(5), 683-693. Available at: https://doi.org/10.1016/j.im.2004.04.003. 
Nielsen, J. (2000). Web-site usability: Usability on the web isn't a luxury. Retrieved from: Http://Www. Informationweek. Com/773/Web. Htm.

Oliveira, T., Alhinho, M., Rita, P., \& Dhillon, G. (2017). Modelling and testing consumer trust dimensions in e-commerce. Computers in Human Behavior, 71, 153-164. Available at: https://doi.org/10.1016/j.chb.2017.01.050.

Park, O.-J., Kim, M. G., \& Ryu, J.-h. (2019). Interface effects of online media on tourists' attitude changes. Tourism Management Perspectives, 30, 262-274. Available at: https://doi.org/10.1016/j.tmp.2019.03.005.

Pavlou, P. A., \& Fygenson, M. (2006). Understanding and predicting electronic commerce adoption: An extension of the theory of planned behavior. MIS Quarterly, 30(1), 115-143. Available at: https://doi.org/10.2307/25148720.

Petter, S., \& McLean, E. R. (2009). A meta-analytic assessment of the DeLone and McLean IS success model: An examination of IS success at the individual level. Information \& Management, 46(3), 159-166. Available at: https://doi.org/10.1016/j.im.2008.12.006.

Reza, J. M., Samiei, N., Dini, B., \& Yaghoubi, M. P. (2012). Examining the structural relationships of electronic word of mouth, destination image, tourist attitude toward destination and travel intention: An integrated approach. Journal of Destination Marketing and Management, 1(1-2), 134-143. Available at: https://doi.org/10.1016/j.jdmm.2012.10.001.

Riscinto-Kozub, K., \& Childs, N. (2012). Conversion of local winery awareness. International Journal of Wine Business Research.

Roca, J. C., Chiu, C.-M., \& Martínez, F. J. (2006). Understanding e-learning continuance intention: An extension of the technology acceptance model. International Journal of Human-computer studies, 64(8), 683-696.

Ryu, M.-H., Kim, S., \& Lee, E. (2009). Understanding the factors affecting online elderly user's participation in video UCC services. Computers in Human Behavior, 25(3), 619-632. Available at: https://doi.org/10.1016/j.chb.2008.08.013.

Serenko, A., \& Turel, O. (2019). A dual-attitude model of system use: The effect of explicit and implicit attitudes. Information $\bigotimes^{\circ}$ Management, 56(5), 657-668. Available at: https://doi.org/10.1016/j.im.2018.10.009.

Shin, D.-H., Shin, Y.-J., Choo, H., \& Beom, K. (2011). Smartphones as smart pedagogical tools: Implications for smartphones as u-learning devices. Computers in Human Behavior, 27(6), 2207-2214. Available at: https://doi.org/10.1016/j.chb.2011.06.017.

Sparrow, B., Liu, J., \& Wegner, D. M. (2011). Google effects on memory: Cognitive consequences of having information at our fingertips. Science, 333(6043), 776-778. Available at: https://doi.org/10.1126/science.1207745.

Stone, M. (1974). Cross-validatory choice and assessment of statistical predictions. Journal of the Royal Statistical Society: Series B (Methodological), 36(2), 111-133. Available at: https://doi.org/10.1111/j.2517-6161.1974.tbo0994.x.

Sullivan, Y. W., \& Kim, D. J. (2018). Assessing the effects of consumers' product evaluations and trust on repurchase intention in e-commerce environments. International Journal of Information Management, 39, 199-219. Available at: https://doi.org/10.1016/j.ijinfomgt.2017.12.008.

Taylor, S., \& Todd, P. A. (1995). Understanding information technology usage: A test of competing models. Information Systems Research, 6(2), 144-176. Available at: https://doi.org/10.1287/isre.6.2.144.

Thong, J. Y., Hong, S.-J., \& Tam, K. Y. (2006). The effects of post-adoption beliefs on the expectation-confirmation model for information technology continuance. International Journal of Human-Computer Studies, 64(9), 799-810. Available at: https://doi.org/10.1016/j.ijhcs.2006.05.001.

Venkatesh, V., \& Davis, F. D. (2000). A theoretical extension of the technology acceptance model: Four longitudinal field studies. Management Science, 46(2), 186-204. Available at: https://doi.org/10.1287/mnsc.46.2.186.11926.

Wang, L., Law, R., Guillet, B. D., Hung, K., \& Fong, D. K. C. (2015). Impact of hotel website quality on online booking intentions: ETrust as a mediator. International Journal of Hospitality Management, 47, 108-115. Available at: https://doi.org/10.1016/j.ijhm.2015.03.012.

Wen, I. (2013). Online shopping of travel products: A study of influence of each dimension of travelers' attitudes and the impact of travelers online shopping experiences on their purchase intentions. International Journal of Hospitality \& Tourism Administration, 14(3), 203-232. 
Xiang, Z., Magnini, V. P., \& Fesenmaier, D. R. (2015). Information technology and consumer behavior in travel and tourism: Insights from travel planning using the internet. Journal of Retailing and Consumer Services, 22, 244-249. Available at: https://doi.org/10.1016/j.jretconser.2014.08.005.

Xiang, Z., Wöber, K., \& Fesenmaier, D. R. (2008). Representation of the online tourism domain in search engines. Journal of Travel Research, 47(2), 137-150. Available at: https://doi.org/10.1177/0047287508321193.

Zhao, J.-D., Huang, J.-S., \& Su, S. (2019). The effects of trust on consumers' continuous purchase intentions in C2C social commerce: A trust transfer perspective. Journal of Retailing and Consumer Services, 50, 42-49. Available at: https://doi.org/10.1016/j.jretconser.2019.04.014.

Zhou, T., Lu, Y., \& Wang, B. (2006). The relative importance of website design quality and service quality in determining consumers. Online Repurchase Behavior, 327-337. Available at: https://doi.org/10.1080/10580530903245663. 